\title{
Sensitivity Study of Four Land Surface Schemes in the WRF Model
}

\author{
Jiming Jin, ${ }^{1}$ Norman L. Miller, ${ }^{2}$ and Nicole Schlegel ${ }^{3}$ \\ ${ }^{1}$ Departments of Watershed Sciences \& Plants, Soils, and Climate, UT 84322-1400 State University, Logan, Utah, USA \\ ${ }^{2}$ Lawrence Berkeley National Laboratory, Earth Sciences Division, Department of Geography, \\ University of California at Berkeley, Berkeley, CA 94720, USA \\ ${ }^{3}$ Department of Earth and Planetary Science, University of California at Berkeley, Beverley, CA 94720, USA
}

Correspondence should be addressed to Jiming Jin, jimingjin99@gmail.com

Received 1 January 2010; Revised 14 April 2010; Accepted 1 May 2010

Academic Editor: Song Y. Hong

Copyright (c) 2010 Jiming Jin et al. This is an open access article distributed under the Creative Commons Attribution License, which permits unrestricted use, distribution, and reproduction in any medium, provided the original work is properly cited.

\begin{abstract}
The Weather Research and Forecasting (WRF) model version 3.0 developed by the National Center for Atmospheric Research (NCAR) includes three land surface schemes: the simple soil thermal diffusion (STD) scheme, the Noah scheme, and the Rapid Update Cycle (RUC) scheme. We have recently coupled the sophisticated NCAR Community Land Model version 3 (CLM3) into WRF to better characterize land surface processes. Among these four land surface schemes, the STD scheme is the simplest in both structure and process physics. The Noah and RUC schemes are at the intermediate level of complexity. CLM3 includes the most sophisticated snow, soil, and vegetation physics among these land surface schemes. WRF simulations with all four land surface schemes over the western United States (WUS) were carried out for the 1 October 1995 through 30 September 1996. The results show that land surface processes strongly affect temperature simulations over the (WUS). As compared to observations, WRFCLM3 with the highest complexity level significantly improves temperature simulations, except for the wintertime maximum temperature. Precipitation is dramatically overestimated by WRF with all four land surface schemes over the (WUS) analyzed in this study and does not show a close relationship with land surface processes.
\end{abstract}

\section{Introduction}

Fossil fuel emissions have caused a $0.6^{\circ} \mathrm{C}$ increase in global temperature during the last 100 years (Hansen et al. [1]), with an anticipated additional $2-5^{\circ} \mathrm{C}$ temperature increase by the end of this century (The Intergovernmental Panel on Climate Change Fourth Assessment Report (IPCC AR4) 2007). Climate change impacts (e.g., extreme heat, severe storms, and air pollution inversion episodes) are especially significant at regional scales, where society and ecosystems are most sensitive (IPCC AR4 2007). Thus, accurate regional climate model (RCM) simulations with reduced uncertainties are needed to better assess the limits of climate change impacts. RCM uncertainties include the spatiotemporal distribution of precipitation, its type, amount, and intensity, snow mass accumulation and melt rates, and daily minimum and maximum temperature. Quantifying these uncertainties and improving operational monthly to interannual regional climate predictions are especially important for sustaining the health of local human and ecosystems environments.
To improve the accuracy of RCM forecasts, we need to understand physical mechanisms and processes that control regional climate change. An important process that regulates regional climate is the global increase in the concentration of atmospheric greenhouse gases (GHGs). It is well recognized that increasing GHG concentrations nonlinearly increases the atmospheric water-holding capacity, resulting in large variations in precipitation events. Theoretically, the ClasiusClapeyron relationship indicates that a $3^{\circ} \mathrm{C}$ temperature increase over the 21 st century will result in a $20 \%$ increase in the atmospheric water-holding capacity [2], leading to an increased likelihood of more severe flood and hydrologic drought conditions (frequency, intensity, and duration). Such an increase in temperature will also change the pressure gradients over the mid-latitudes, shifting storm tracks poleward [3] and strengthening the likelihood of droughts in parts of the US. The El Niño-Southern Oscillation (ENSO) also changes global climate circulation and alters atmospheric moisture transport. The western United States (WUS) is a particularly vulnerable dipole, where ENSO 


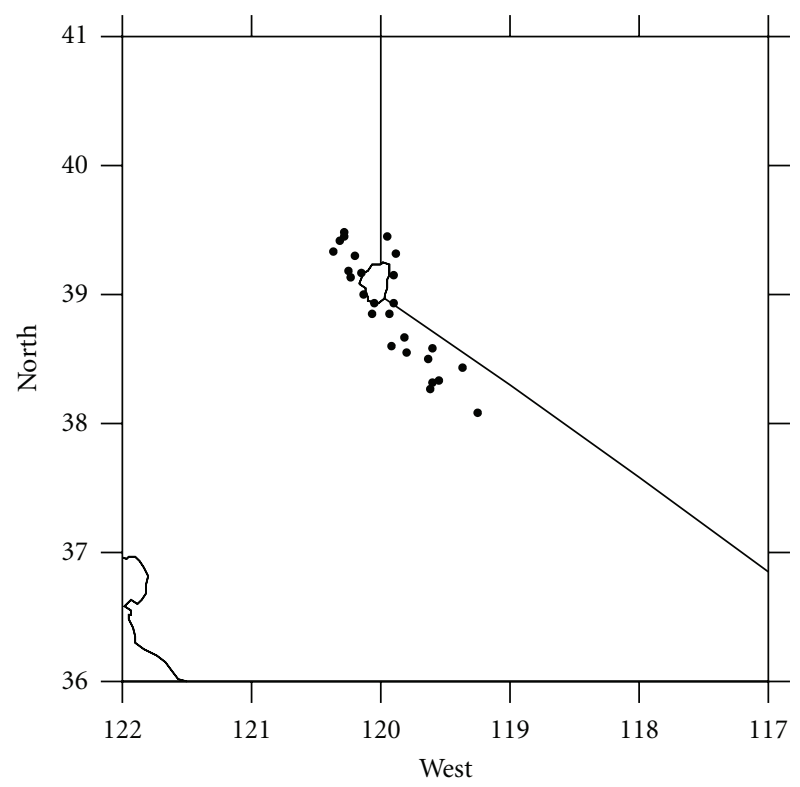

Figure 1: 26 Snotel Stations located in the California and Nevada areas.

episodes produce anomalously wet (dry) winter precipitation and snow mass amount and spatial distribution in the southern (northern) WUS [4].

In addition to the role of global-scale climate change, the regional climate system is often disturbed by landsurface and land use changes due to human activities (e.g., agricultural expansion, urbanization) and natural processes (e.g., drought-related vegetation mortality in the U.S. southwest and global-warming-induced snow cover and glacier retreat). Breshears et al. [5] indicate that a recent drought in the southern WUS resulted in significant vegetation mortality, with reduction in vegetation abundance that further modified the surface flux exchanges between the land surface and atmosphere and ultimately reduced cloudiness and precipitation [6] and raised the temperature [7].

Regional climate forecasts have advanced at the European Centre for Medium-Range Weather Forecasts [8], the Australian Commonwealth Scientific and Research Organization [9], and the National Centers for Environmental Predictions (NCEP) [10]. These efforts are based on numerical computer models at global or near-global scales. However, the horizontal spatial resolution for current climate forecasts ranges over hundreds of kilometers and is too coarse to provide important details of sub- $100 \mathrm{~km}$ regional-scale climate phenomena and processes. It is well acknowledged that RCMs with spatial resolution at or coarser than $30 \mathrm{~km}$ are unable to produce accurate precipitation forecasts for the California mountainous areas [11], and that global climate models at resolutions of $30 \mathrm{~km}$ or higher require computing and human resources that are currently not feasible, especially if multiyear ensemble integrations are required. At present, only a few operational institutions are capable of this level of computation and data storage, while the majority of global climate models usually have oversimplified

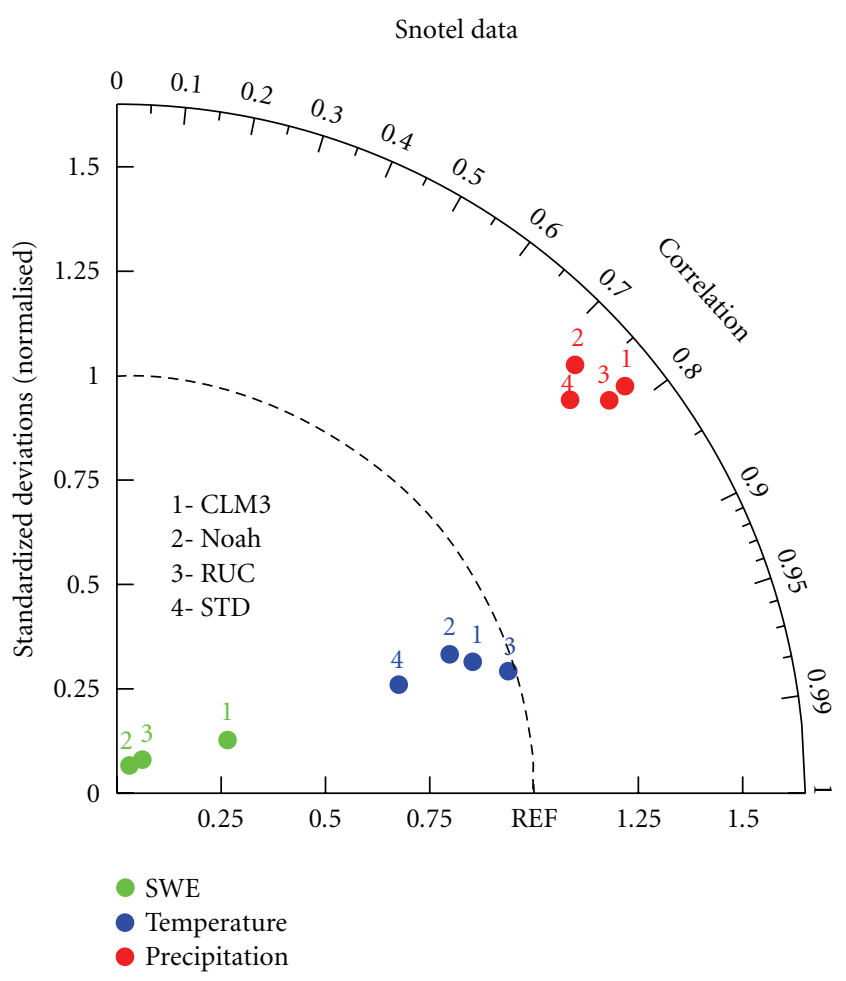

FIgUre 2: Comparison of the WRF-simulations with CLM3, Noah, RUC, and STD land surface schemes. Green dots are for SWE, red dots are for precipitation, and blue dots are for temperature. The standard deviations and correlation coefficients are derived from the daily simulations and observations for 1 October 1995 through 30 September 1996.

physics and parameterized structures that are unable to adequately describe regional-scale processes and phenomena with sufficient accuracy. Therefore, RCMs driven by global climate forecast products are more appropriate tools to overcome these limitations for exploring regional climate predictability.

In this study, the Weather Research, and Forecasting (WRF) model version 3.0 developed by the National Center for Atmospheric Research (NCAR) is used to perform regional climate simulations over the WUS. The WRF model is a limited-area, nonhydrostatic, terrain-following sigmacoordinate model designed to simulate or predict regional weather and climate. This model represents the recent advances of RCMs that combine the expertise and experience for mesoscale meteorology and land-surface and climate science developed over the last several decades. The version 3.0 of the WRF model includes three land surface schemes, which are the simple soil thermal diffusion (STD) scheme, the Noah scheme (Ek and Mahrt [12]), and the Rapid Update Cycle (RUC; $[13,14]$ ) scheme. However, the snow physics in these land surface schemes embedded in WRF is oversimplified. The lack of a dynamic vegetation component within these schemes makes WRF unable to simulate future climate-forced vegetation shifts. Hence, we have recently coupled the advanced NCAR Community Land Model version 3 (CLM3) [15] into WRF to better characterize land 


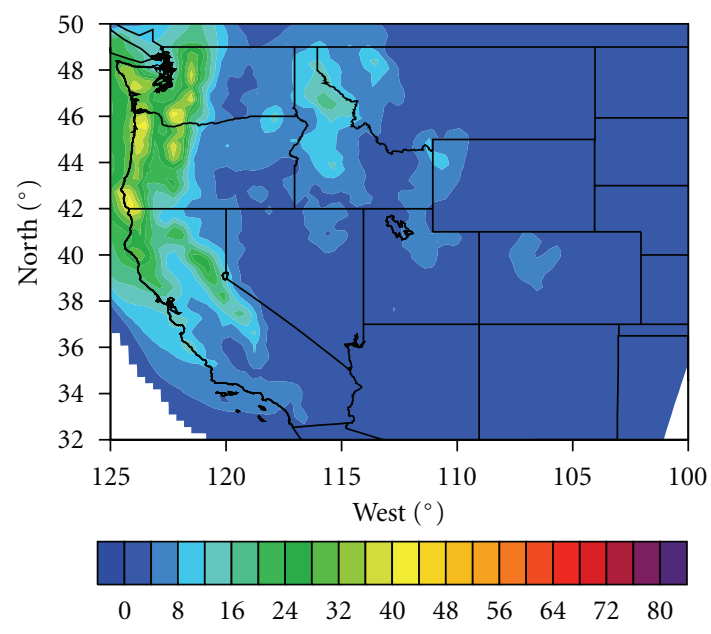

(a)

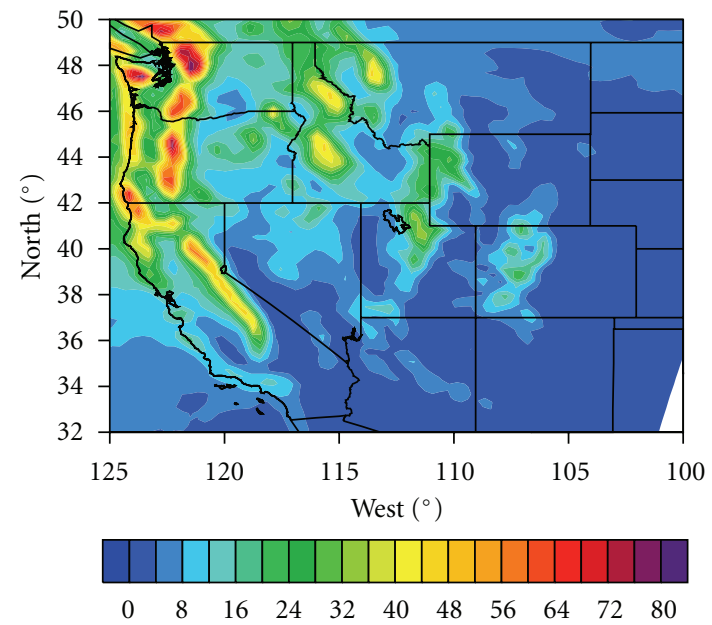

(b)

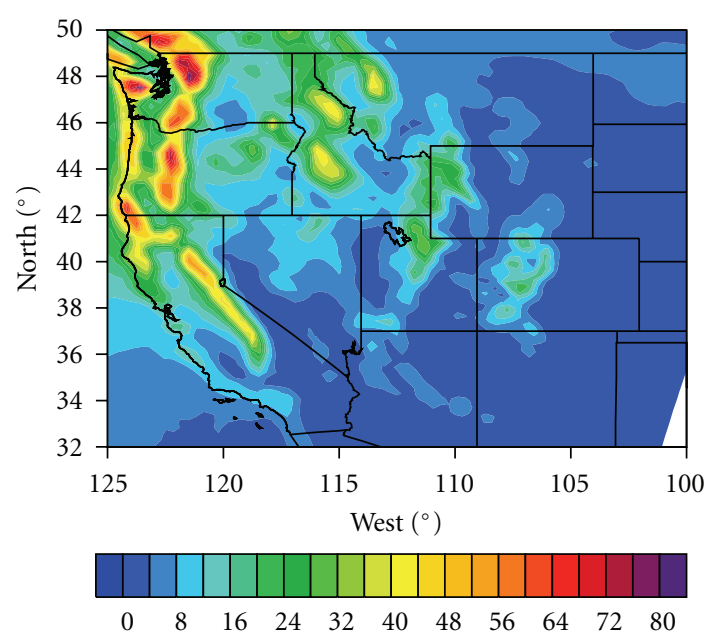

(d)

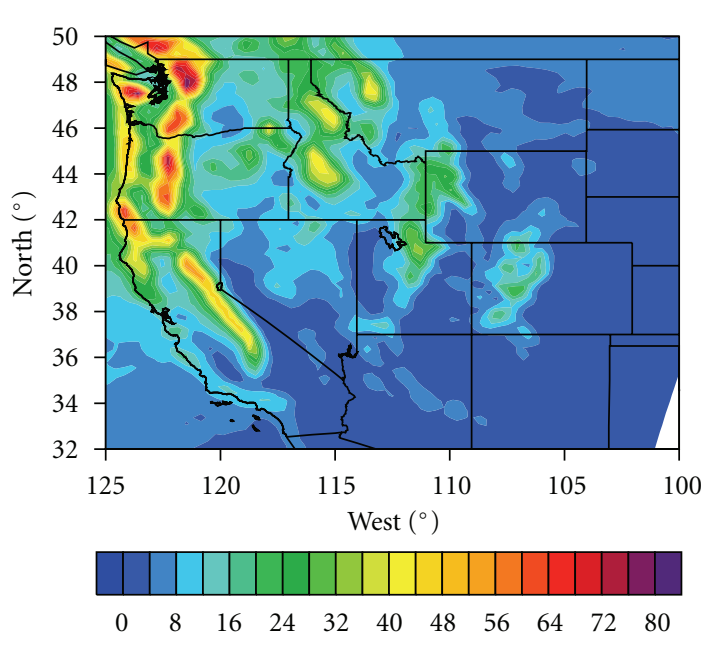

(c)

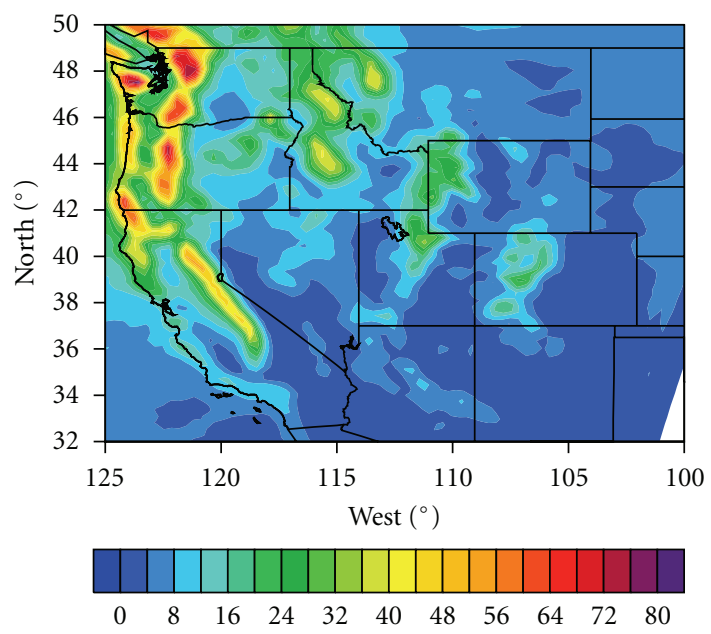

(e)

FIGURE 3: The geographic distribution of observed and WRF-simulated monthly winter precipitation (Unit: mm) averaged over November 1995 through March 1996. (a) Observations; (b) CLM3; (c) Noah; (d) RUC; (e) STD. 


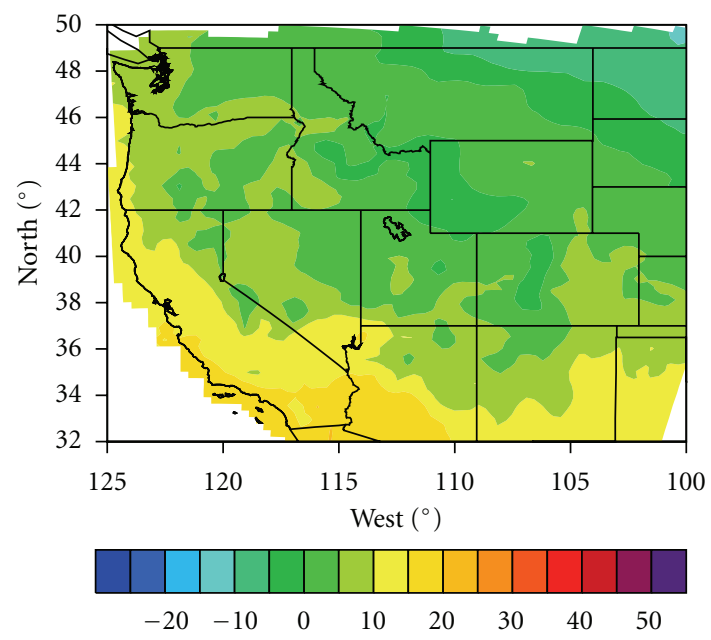

(a)

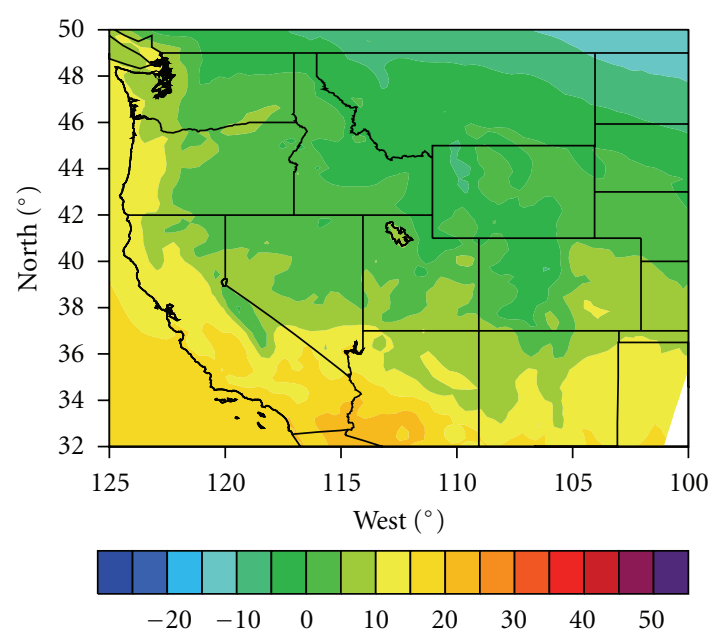

(b)

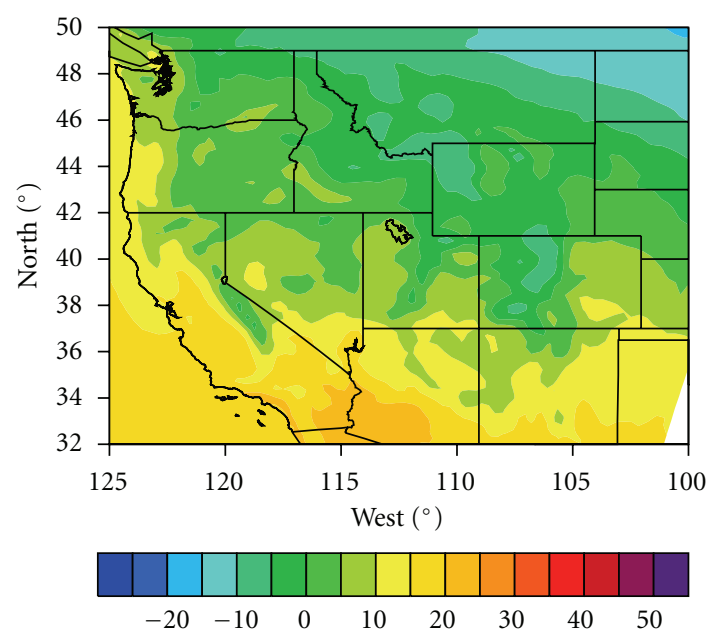

(d)

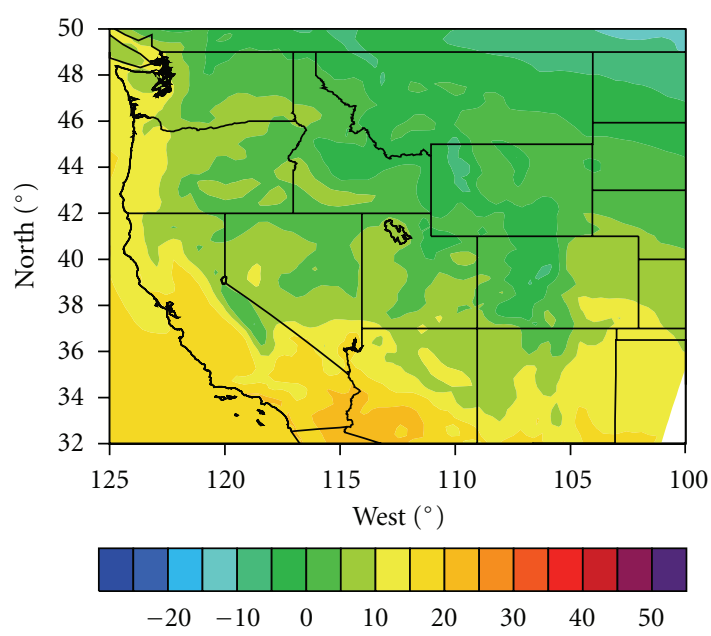

(c)

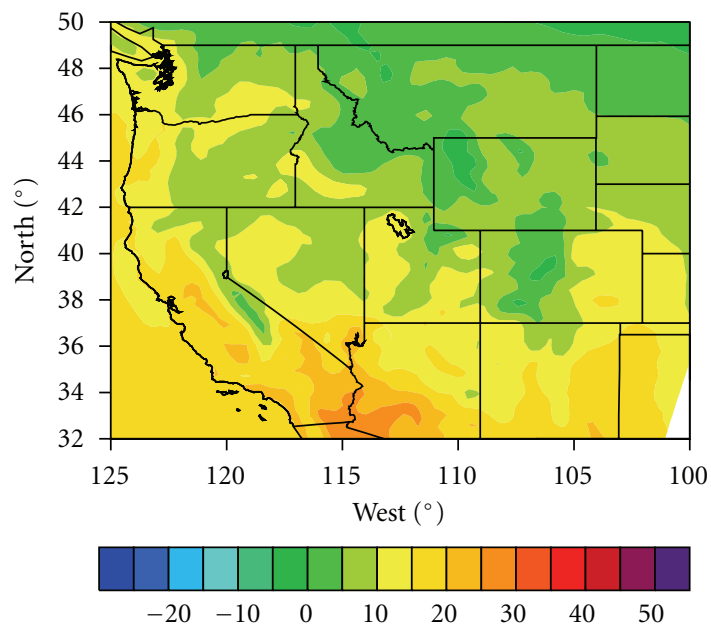

(e)

FIGURE 4: The geographic distribution of observed and WRF-simulated winter (December, January, and February) daily maximum temperature (Unit: $\left.{ }^{\circ} \mathrm{C}\right)$. (a) Observations; (b) CLM3; (c) Noah; (d) RUC; (e) STD. 


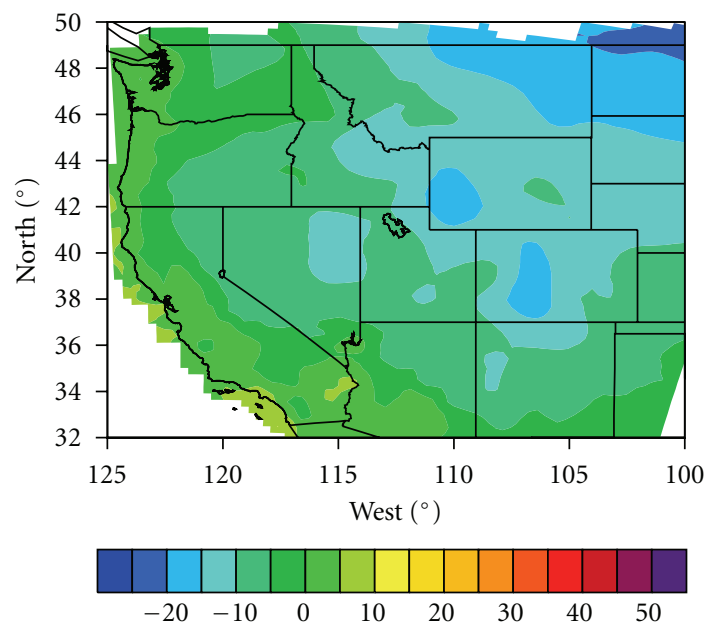

(a)

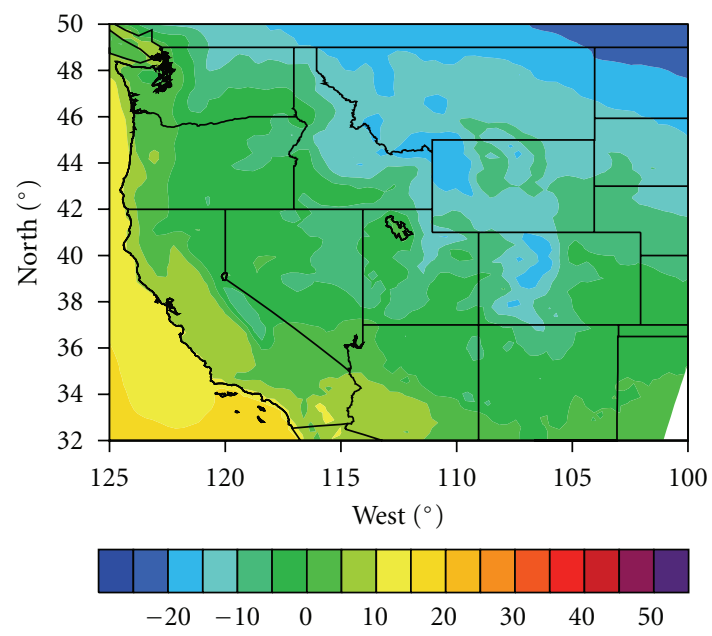

(b)

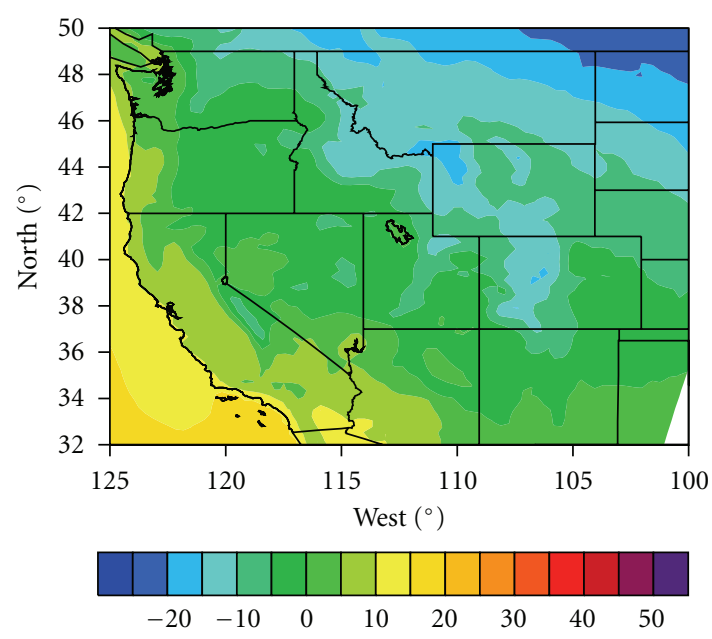

(d)

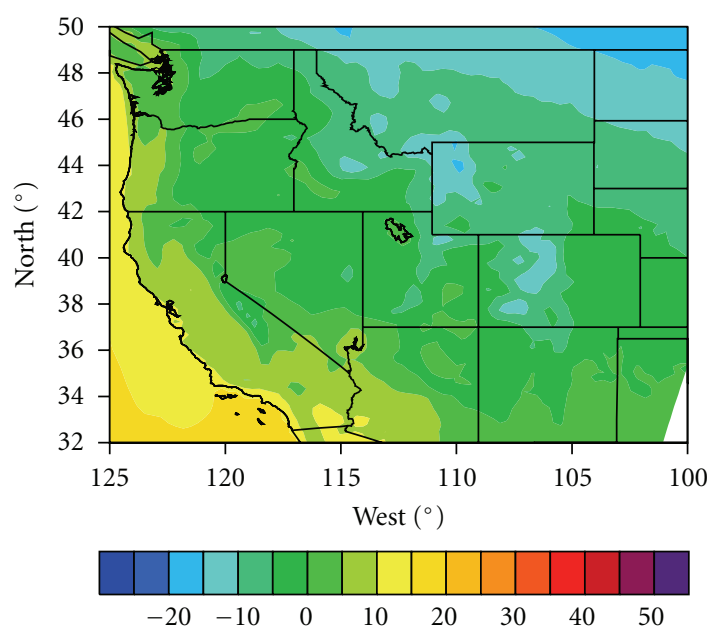

(c)

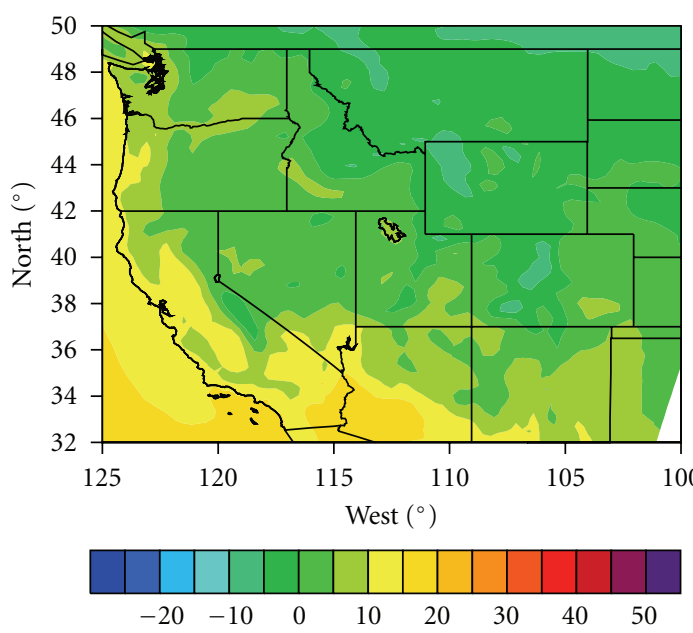

(e)

FIGURE 5: The geographic distribution of observed and WRF-simulated winter (December, January, and February) daily minimum temperature (Unit: ${ }^{\circ} \mathrm{C}$ ). (a) Observations; (b) CLM3; (c) Noah; (d) RUC; (e) STD. 


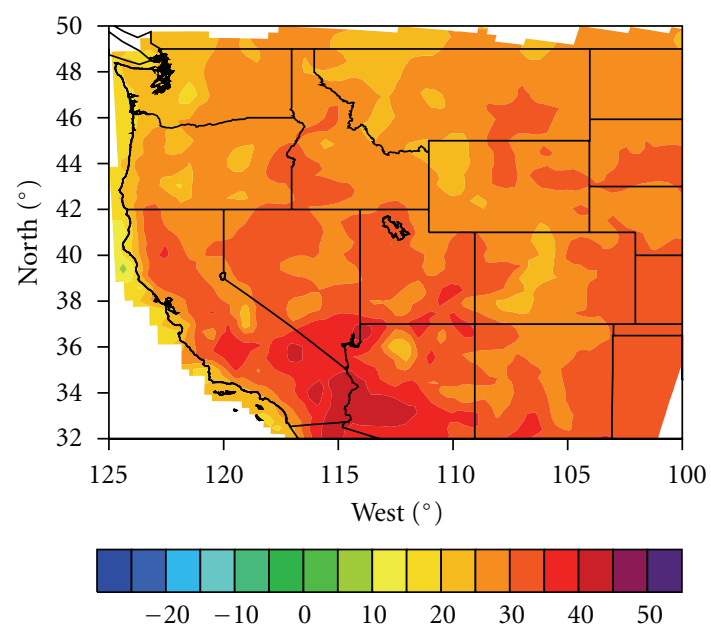

(a)

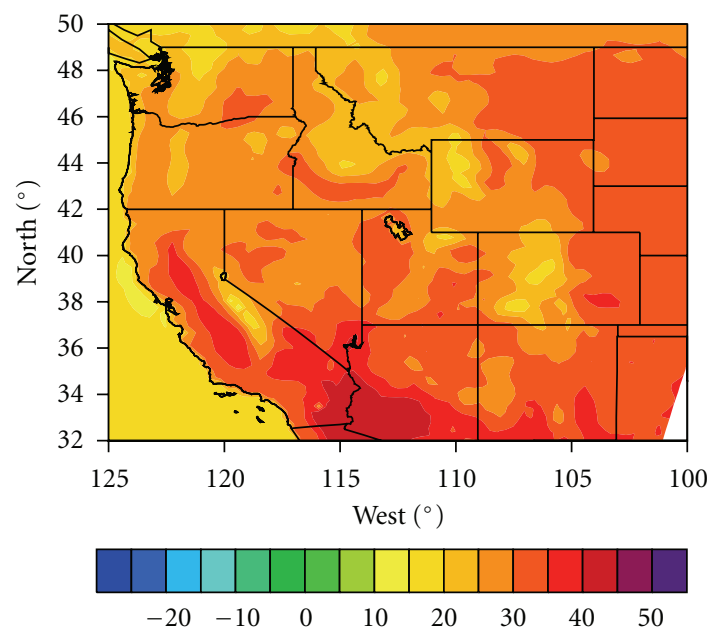

(b)

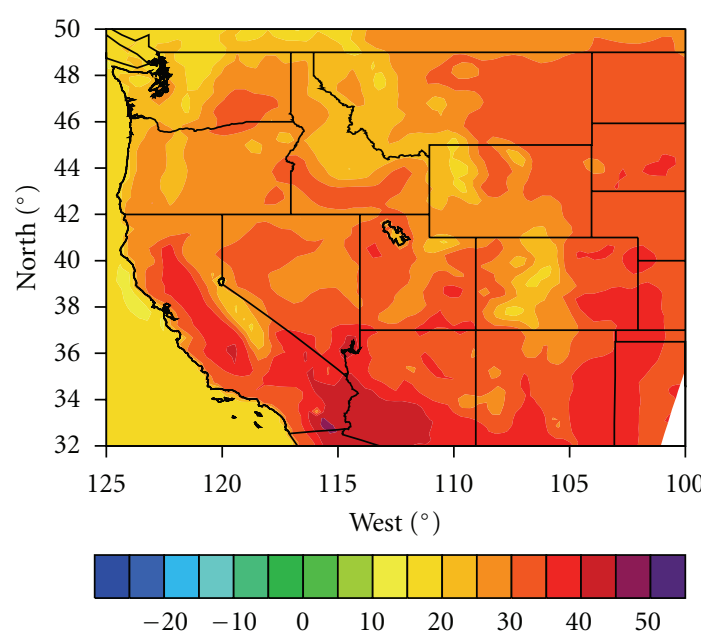

(d)

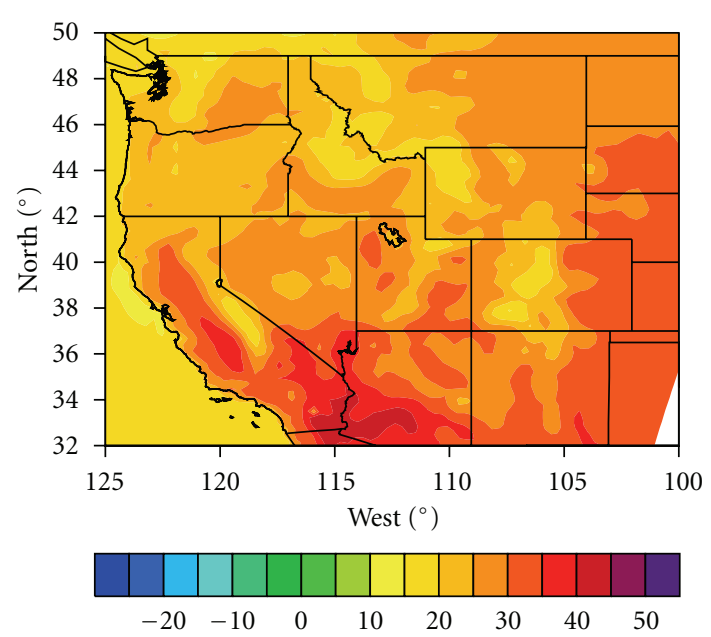

(c)

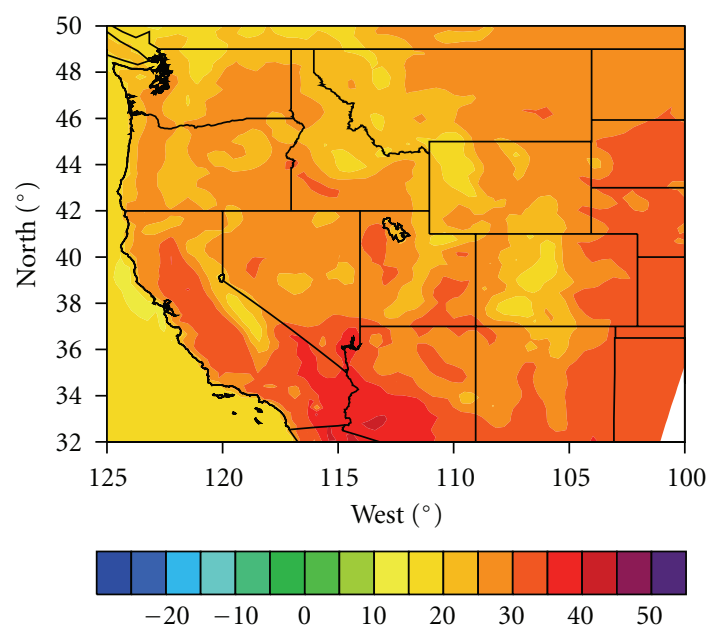

(e)

FIGURE 6: The geographic distribution of observed and WRF-simulated summer (June, July, and August) daily maximum temperature (Unit: ${ }^{\circ}$ C). (a) Observations; (b) CLM3; (c) Noah; (d) RUC; (e) STD. 
TABLE 1: Comparison of the STD, Noah, RUC, and CLM3 land surface schemes in WRF.

\begin{tabular}{|c|c|c|c|c|c|}
\hline & Vegetation & Soil & Snow & Lake & River routing \\
\hline STD & N/A & $\begin{array}{l}5 \text { layer temperatures, } \\
\text { but no moisture and } \\
\text { frozen soil }\end{array}$ & N/A & N/A & N/A \\
\hline Noah & $\begin{array}{l}\text { One vegetation type in one grid } \\
\text { cell without dynamic vegetation } \\
\text { and carbon budget }\end{array}$ & $\begin{array}{l}4 \text { layer temperatures } \\
\text { and moistures and } \\
\text { frozen soil }\end{array}$ & $\begin{array}{l}1 \text { layer snow lumped } \\
\text { with the top soil layer } \\
\text { No liquid water fixed } \\
\text { snow density }\end{array}$ & N/A & N/A \\
\hline RUC & $\begin{array}{l}\text { One vegetation type in one grid } \\
\text { cell without dynamic vegetation } \\
\text { and carbon budget }\end{array}$ & $\begin{array}{l}6 \text { layer temperatures } \\
\text { and moistures and } \\
\text { frozen soil }\end{array}$ & $\begin{array}{l}2 \text { layer snow No } \\
\text { liquid water Fixed } \\
\text { snow density }\end{array}$ & N/A & N/A \\
\hline CLM3 & $\begin{array}{l}\text { Subgrids with up to } 10 \text { vegetation } \\
\text { types in one grid cell with dynamic } \\
\text { vegetation and carbon budget }\end{array}$ & $\begin{array}{l}\text { 10-layer temperatures } \\
\text { and moistures and } \\
\text { frozen soil }\end{array}$ & $\begin{array}{l}5 \text { layer snow with } \\
\text { liquid water Variable } \\
\text { snow density }\end{array}$ & $\begin{array}{l}10 \text { layer lake with } \\
\text { lake ice and snow } \\
\text { included }\end{array}$ & $\begin{array}{l}\text { A Digital Elevation } \\
\text { Model (DEM) to } \\
\text { calculate water flow } \\
\text { directions }\end{array}$ \\
\hline
\end{tabular}

surface processes and their feedbacks to the atmosphere. The application of the coupled WRF-CLM3 uniquely adds a special strength to this study, as CLM3 reflects the most recent development of land surface process modeling [1517]. The dynamic vegetation scheme in CLM3 now enables WRF to predict future climate-related vegetation changes. A simple comparison of the features within these four land surface schemes in WRF is given in Table 1.

The objective of this study is to quantify the role of land surface processes in the regional climate system by performing a series of WRF runs using the four available land surface scheme options (STD, Noah, RUC, and CLM3) with their different complexity levels. Among these four schemes (Table 1), the STD scheme is the simplest, where only soil temperature is calculated. The representations of snow, vegetation, and soil moisture processes are missed. The Noah and RUC schemes are at the intermediate level of complexity, but RUC has a relatively more complex snow scheme when compared to Noah (Table 1). CLM3 includes the most sophisticated snow, soil, and vegetation physics among the four land surface schemes. Comparison of these land surface schemes coupled with WRF can lead to a better understanding of how land surface processes affect regional climate and also give insight on how the level of the land surface model complexity affects the accuracy of regional climate simulations.

\section{Methodology and Data}

As mentioned above, CLM3 was recently coupled with the WRF model. The initialization of CLM3 follows the same setup as that of Noah and RUC and is performed in the WRF initialization module. Atmospheric variables at the lowest atmospheric level (about 50 meter height) are inputted into the CLM3 module to force land surface processes. These atmospheric variables include incoming solar radiation, longwave radiation, temperature, specific humidity, wind speed, precipitation, and surface pressure. The reflected solar radiation, surface longwave emission, and latent and sensible heat fluxes are outputted to the atmospheric modules in WRF.

Four WRF runs with the available land surface schemes (STD, Noah, RUC, and CLM3) were performed with a $30 \mathrm{~km}$ resolution for a domain that includes the WUS $\left(31^{\circ} \mathrm{N} 125^{\circ} \mathrm{W}\right.$, $50^{\circ} \mathrm{N} 100^{\circ} \mathrm{W}$ ). These WRF runs were for 1 September 1995 through 30 September 1996 representing a total integration period of 13 months. The first month of model outputs is discarded to alleviate the effects of the model initializations, and the remaining one-year simulations are analyzed. This period was chosen, because the Sea Surface Temperature (SST) over the tropical Pacific region is under normal conditions during 1995-1996 [18], and the climate pattern shows a similarity to its climatology over our study area, the WUS. By choosing a neutral ENSO year, we are able to effectively identify the regional impact of land surface processes that can often be mixed within anomalous weather and climate conditions [19].

In WRF, all the model atmospheric settings are exactly the same except for the land-surface schemes. The KainFritsch convection scheme is chosen to parameterize cumulus clouds [20]. The Yonsei University (YSU) planetary boundary layer (PBL) scheme [21] is applied to solve boundary layer processes. The microphysics scheme selected is the WRF Single-Moment 3-class (WSM3) scheme [22]. The Rapid Radiative Transfer Model (RRTM) based on Mlawer et al. [23] is selected for describing longwave radiation transfer within the atmosphere and to the surface, and the shortwave scheme chosen is that developed by Dudhia [24].

The National Centers for Environmental PredictionDepartment of Energy Atmospheric Model Intercomparison Project II Reanalysis (NCEP-2) data were used for the WRF initial conditions that include initial soil temperature and moisture in the Noah, RUC, and CLM land surface schemes. In STD, only soil temperatures were initialized, and no soil moistures were calculated. The NCEP-2 data were also used for the lateral boundary conditions and the SST in WRF that were updated every six hours. The WRF outputs 
were saved hourly. Here, we evaluate the model performance with 26 observation sites from the Snow Telemetry (Snotel; http://www.wcc.nrcs.usda.gov/snow/) station data over the Sierra Nevada area that include daily snow water equivalent (SWE), $2 \mathrm{~m}$ height temperature, and precipitation (Figure 1). Gridded daily maximum and minimum temperature $\left(0.5^{\circ} \times 0.5^{\circ}\right.$ resolution $)$ and precipitation $\left(0.25^{\circ} \times 0.25^{\circ}\right.$ resolution) data were used to examine the spatial distribution of simulated temperature and precipitation. Both temperature and precipitation datasets were developed by the National Oceanic and Atmospheric Administration Climate Prediction Center.

\section{Results}

Precipitation, temperature, and snow water equivalent (SWE) simulations from the four WRF runs at $30 \mathrm{~km}$ resolution with different land surface schemes are compared in a Taylor diagram (Figure 2). These simulations are the average over the 26 Snotel stations that are located in the Sierra Nevada region (Figure 1). All the simulated variables from different land surface schemes have high correlations with observations. The correlation coefficients for precipitation are between 0.7 and 0.8 for all models and for temperature are above 0.9 . The correlation coefficient for the CLM3 SWE is above 0.9 , and it is slightly lower than 0.9 for the Noah and RUC SWEs. These results show that the WRF code can well simulate the phases of the variations in these variables. However, the simulated standard deviations exhibit a large range. The temperature standard deviation has the best range of values among these variables, the standard deviation is overestimated for precipitation and underestimated for SWE, indicating the WRF model, regardless of the land surface scheme, produces large errors in simulating the magnitude of precipitation and SWE. SWE is best simulated in CLM3, where the most sophisticated snow physics is included, when compared to the Noah and RUC land surface schemes, however, SWE is not predicted in STD. In addition, without SWE and vegetation components in the STD model, WRFSTD produces the lowest temperature standard deviation, implying that the seasonal evolution of SWE and vegetation amplifies the temperature variations.

Figure 3 shows the spatial distribution of monthly precipitation averaged over November 1995 through March 1996, a period when a significant amount of precipitation generated. It is seen that the WRF model with the different land surface schemes can reasonably simulate the spatial pattern of the precipitation, but the domain-wide averaged precipitation amounts are more than doubled by WRF (Table 2), as compared to observations. The change of the land surface scheme in WRF does not significantly change the precipitation simulations, indicating that the overestimated precipitation most possibly is related to atmospheric processes and the reanalysis data used for initial and lateral boundary conditions. The summer precipitation is not shown here, because it is quite small in magnitude when compared to the winter precipitation for the WUS. Figures
TABle 2: Domain-wide averaged observations and simulations for precipitation and surface air temperature as shown in Figure 2. Summer is June, July, and August, and winter for temperature is December, January, and February. Precipitation is for November 1995 through March 1996 only.

\begin{tabular}{lllllll}
\hline & & OBS & CLM & NOAH & RUC & STD \\
\hline \multirow{2}{*}{ Summer } & $T \max \left({ }^{\circ} \mathrm{C}\right)$ & 29.1 & 28.1 & 25.6 & 28.7 & 26.1 \\
& $T \operatorname{Tmin}\left({ }^{\circ} \mathrm{C}\right)$ & 11.6 & 11.7 & 13.2 & 13.9 & 13.4 \\
\hline \multirow{4}{*}{ Winter } & $T \max \left({ }^{\circ} \mathrm{C}\right)$ & 5.5 & 2.9 & 4.2 & 2.5 & 8.7 \\
& $T \min \left({ }^{\circ} \mathrm{C}\right)$ & -7.4 & -6.4 & -3.4 & -5.3 & 2.0 \\
& $\begin{array}{c}P r e c i p \\
(\mathrm{~cm} / \text { month) }\end{array}$ & 4.8 & 10.7 & 10.7 & 10.4 & 10.9 \\
\hline
\end{tabular}

4, 5, 6, and 7 show winter (December, January, and February) and summer (June, July, and August) maximum and minimum temperature (hereafter Tmax and Tmin, resp.), observations and simulations. The simulated temperature spatial patterns are similar to the observations in these four maps. WRF-CLM3 produces the best results for winter Tmin and both summer Tmax and Tmin among the four land surface schemes (Table 2). However, this most sophisticated model of the four does not show any advantage in computing winter Tmax, where a $2.6^{\circ} \mathrm{C}$ cold bias is seen, and WRFRUC gives a similar result. In the winter Tmax maps, it is seen that both CLM3 and RUC underestimate the temperature mostly over snow abundant mountainous areas (e.g., western Montana and nearby areas) where stronger precipitation occurs (Figure 3 ). Therefore, it is speculated that the overestimated precipitation simulated in these areas results in a larger snow cover area than observations, leading to more solar radiation reflected during the daytime, and in turn, lower surface air temperature. In WRF-CLM3 and WRF-RUC with a multilayer snow scheme, the erroneous precipitation has a more severe impact on snow simulations than in WRF-Noah, where snow is lumped with the top soil layer, with underestimated snow mass and snow cover area often seen [11]. As such, Tmax is only $1.3^{\circ} \mathrm{C}$ lower in WRF-Noah than the observations, and WRF-STD, which does not have a snow scheme and produces a $3.2^{\circ} \mathrm{C}$ higher Tmax. Similar cold biases are not seen in WRF-CLM3 and WRF-RUC during the nighttime when solar radiation is not present, which further verifies our speculation. Table 2 shows that all land surface models in WRF overestimate the winter surface air temperature during the nighttime, but CLM3 gives the closest result, indicating that detailed descriptions of land surface processes in CLM3 play a role in such an improvement.

Based on the above discussion, it is shown that the most sophisticated model, WRF-CLM3, improves surface air temperature simulations, except for winter Tmax, when compared to WRF with the other three land surface schemes. While the simplest model, WRF-STD, produces the worst results for Tmax. Although an improvement in snow simulation is seen in WRF-CLM3 over the Sierra Nevada region, the overall performance for snow simulation is still unable to be fully judged due to the erroneous precipitation simulations 

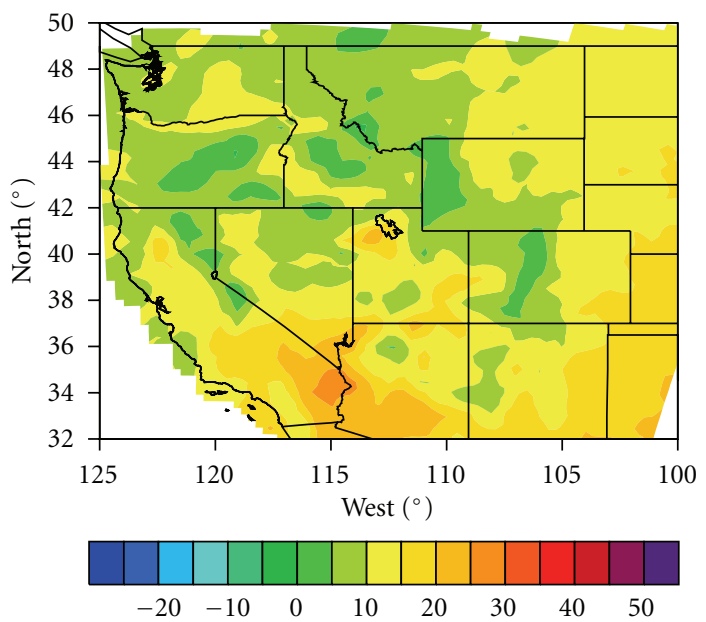

(a)

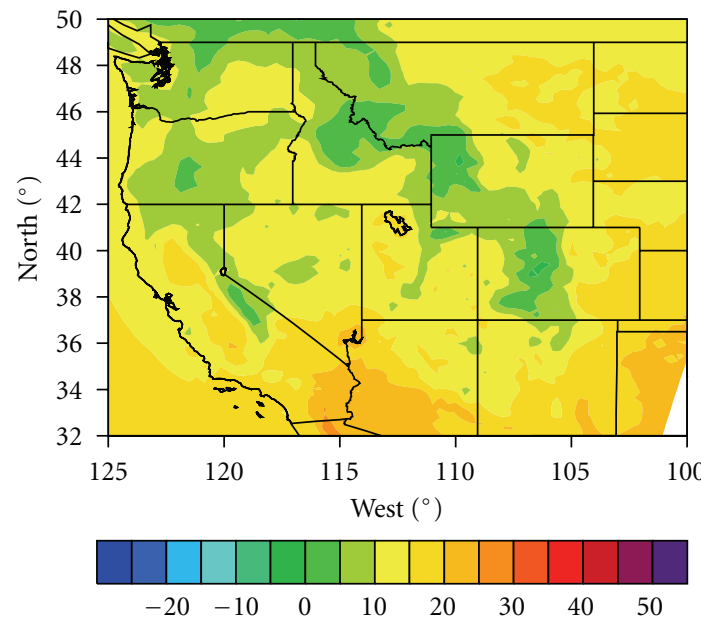

(b)

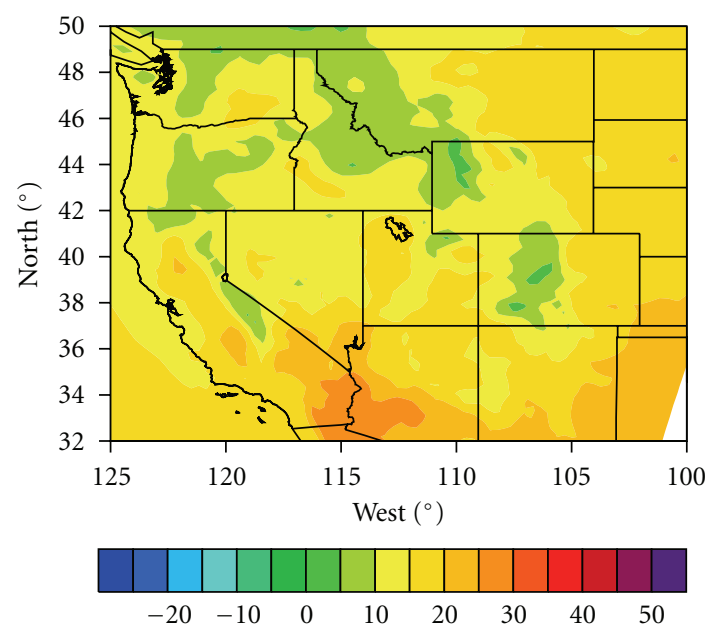

(d)

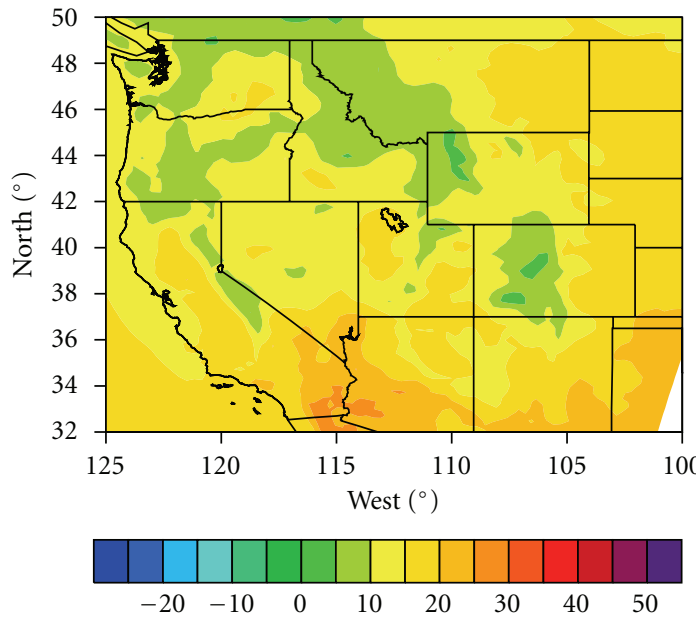

(c)

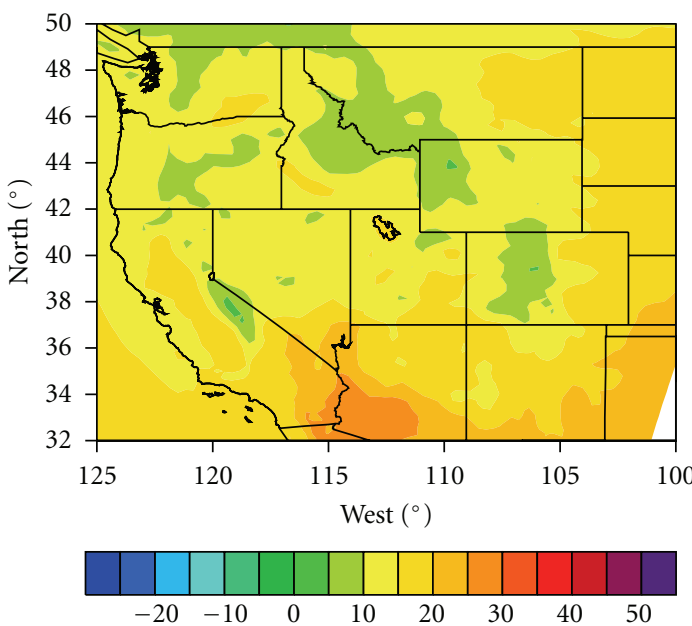

(e)

FIGURE 7: The geographic distribution of observed and WRF-simulated summer (June, July, and August) daily minimum temperature (Unit: $\left.{ }^{\circ} \mathrm{C}\right)$. (a) Observations; (b) CLM3; (c) Noah; (d) RUC; (e) STD. 
that are found to be largely independent of the land surface schemes.

\section{Conclusions and Discussions}

The objective of this study is to quantitatively understand the role of land surface processes in the regional climate system using the state-of-the-art WRF model coupled with four land surface schemes each with different levels of complexity (STD, Noah, RUC, and CLM3). The coupling of WRFCLM3 represents our most recent effort to improve landsurface process simulations and predictions in the regional climate system. The results from WRF with these landsurface schemes show that land-surface processes strongly affect temperature simulations. The coupling of WRF-CLM3 with the highest complexity level improves the temperature simulations to a large extent (except for winter Tmax). Precipitation over the WUS is significantly overestimated by all four of the WRF land surface schemes analyzed here. However, this overestimation does not show a close relationship with land surface processes. As such, the resulting snow simulations cannot be quantitatively evaluated, although an improvement in snow simulation is found in WRF-CLM3 over the Sierra Nevada area.

To better estimate precipitation in WRF, more extensive modeling experiments are being performed. These experiments include the tests with several sets of combinations of radiation schemes, different cumulus parameterizations, PBL schemes, and microphysics schemes that have been embedded in the WRF model. Additionally, spatial resolution and domain size need to factor into the accuracy of these WUS precipitation simulations

\section{Acknowledgments}

Jiming Jin was supported by the Utah Agricultural Experiment Station, USDA Special Grants no. 2008-34610-19175 and no. 2009-34610-19925. The study was also supported by the NOAA CPPA Grant no. NA090AR4310195.

\section{References}

[1] J. Hansen, M. Sato, R. Ruedy, K. Lo, D. W. Lea, and M. Medina-Elizade, "Global temperature change," Proceedings of the National Academy of Sciences of the United States of America, vol. 103, no. 39, pp. 14288-14293, 2006.

[2] I. M. Held and B. J. Soden, "Robust responses of the hydrological cycle to global warming," Journal of Climate, vol. 19, no. 21, pp. 5686-5699, 2006.

[3] C. M. Mitas and A. Clement, "Has the Hadley cell been strengthening in recent decades?" Geophysical Research Letters, vol. 32, no. 3, pp. 1-5, 2005.

[4] J. Jin, N. L. Miller, S. Sorooshian, and X. Gao, "Relationship between atmospheric circulation and snowpack in the western USA," Hydrological Processes, vol. 20, no. 4, pp. 753-767, 2006.

[5] D. D. Breshears, N. S. Cobb, P. M. Rich et al., "Regional vegetation die-off in response to global-change-type drought," Proceedings of the National Academy of Sciences of the United States of America, vol. 102, no. 42, pp. 15144-15148, 2005.
[6] C. P. Weaver and R. Avissar, "Atmospheric disturbances caused by human modification of the landscape," Bulletin of the American Meteorological Society, vol. 82, no. 2, pp. 269-281, 2001.

[7] G. B. Bonan, "Effects of land use on the climate of the United States," Climatic Change, vol. 37, no. 3, pp. 449-486, 1997.

[8] D. L. T. Anderson, "Comparison of the ECMWF seasonal forecast systems 1 and 2, including the relative performance for the 1997/8 El Niño," Tech. Rep. Technical Memoranda 404, ECMWF, Shinfield Park, Reading, UK, 2003.

[9] G. Wang, R. Kleeman, N. Smith, and F. Tseitkin, "The BMRC coupled general circulation model ENSO forecast system," Monthly Weather Review, vol. 130, no. 4, pp. 975-991, 2002.

[10] S. Saha, S. Nadiga, C. Thiaw et al., "The NCEP climate forecast system," Journal of Climate, vol. 19, no. 15, pp. 3483-3517, 2006.

[11] J. Jin and N. L. Miller, "Analysis of the impact of snow on daily weather variability in mountainous regions using MM5," Journal of Hydrometeorology, vol. 8, no. 2, pp. 245-258, 2007.

[12] M. Ek and L. Mahrt, OSU 1-D PBL Model User's Guide. Version1.04, Department of Atmospheric Sciences, Oregon State University, Corvallis, Ore, USA, 1991.

[13] T. G. Smirnova, J. M. Brown, and S. G. Benjamin, "Performance of different soil model configurations in simulating ground surface temperature and surface fluxes," Monthly Weather Review, vol. 125, no. 8, pp. 1870-1884, 1997.

[14] T. G. Smirnova, J. M. Brown, S. G. Benjamin, and D. Kim, "Parameterization of cold-season processes in the MAPS landsurface scheme," Journal of Geophysical Research D, vol. 105, no. 3, pp. 4077-4086, 2000.

[15] K. W. Oleson, Y. Dai, G. Bonan, et al., "Technical description of the community land model (CLM)," Tech. Note NCAR/TN461+STR, National Center for Atmospheric Research, Boulder, Colo, USA, 2004.

[16] G. B. Bonan, K. W. Oleson, M. Vertenstein et al., "The land surface climatology of the community land model coupled to the NCAR community climate model," Journal of Climate, vol. 15, no. 22, pp. 3123-3149, 2002.

[17] X. Zeng, M. Shaikh, Y. Dai, R. E. Dickinson, and R. Myneni, "Coupling of the common land model to the NCAR community climate model," Journal of Climate, vol. 15, no. 14, pp. 1832-1854, 2002.

[18] K. E. Trenberth, “The definition of El Niño," Bulletin of the American Meteorological Society, vol. 78, no. 12, pp. 27712777, 1997.

[19] J. J. Feddema, K. W. Oleson, G. B. Bonan et al., "Atmospheric science: the importance of land-cover change in simulating future climates," Science, vol. 310, no. 5754, pp. 1674-1678, 2005.

[20] J. S. Kain and J. M. Fritsch, "Convective parameterization for mesoscale models: the Kain-Fritcsh scheme," in The Representation of Cumulus Convection in Numerical Models, $\mathrm{K}$. A. Emanuel and D. J. Raymond, Eds., p. 246, The American Meteor Society, 1993.

[21] S.-Y. Hong and H.-L. Pan, "Nonlocal boundary layer vertical diffusion in a medium-range forecast model," Monthly Weather Review, vol. 124, no. 10, pp. 2322-2339, 1996.

[22] S.-Y. Hong, J. Dudhia, and S.-H. Chen, "A revised approach to ice microphysical processes for the bulk parameterization of clouds and precipitation," Monthly Weather Review, vol. 132, no. 1, pp. 103-120, 2004. 
[23] E. J. Mlawer, S. J. Taubman, P. D. Brown, M. J. Iacono, and S. A. Clough, "Radiative transfer for inhomogeneous atmospheres: RRTM, a validated correlated-k model for the longwave," Journal of Geophysical Research D, vol. 102, no. 14, pp. 1666316682, 1997.

[24] J. Dudhia, "Numerical study of convection observed during the Winter Monsoon Experiment using a mesoscale twodimensional model," Journal of the Atmospheric Sciences, vol. 46, no. 20, pp. 3077-3107, 1989. 

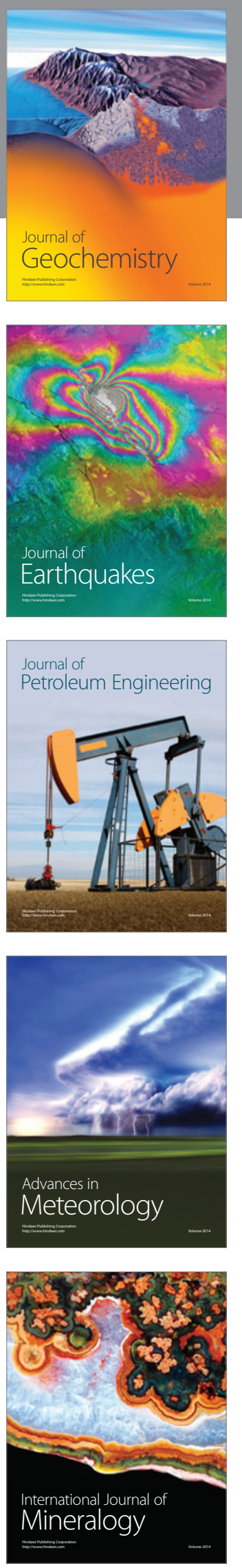
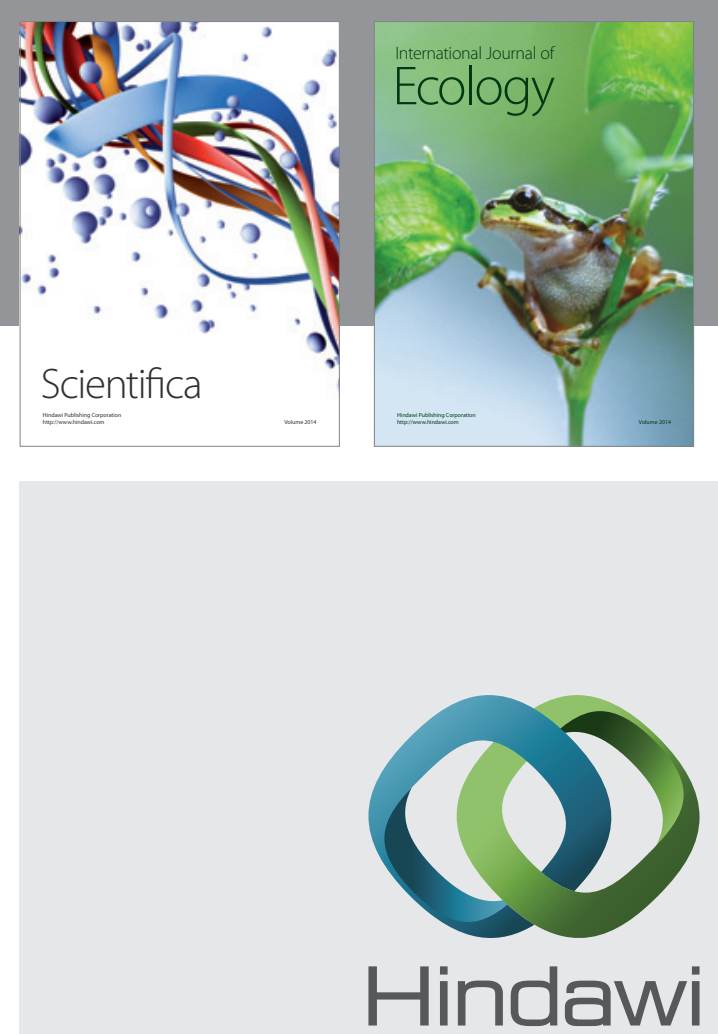

Submit your manuscripts at http://www.hindawi.com
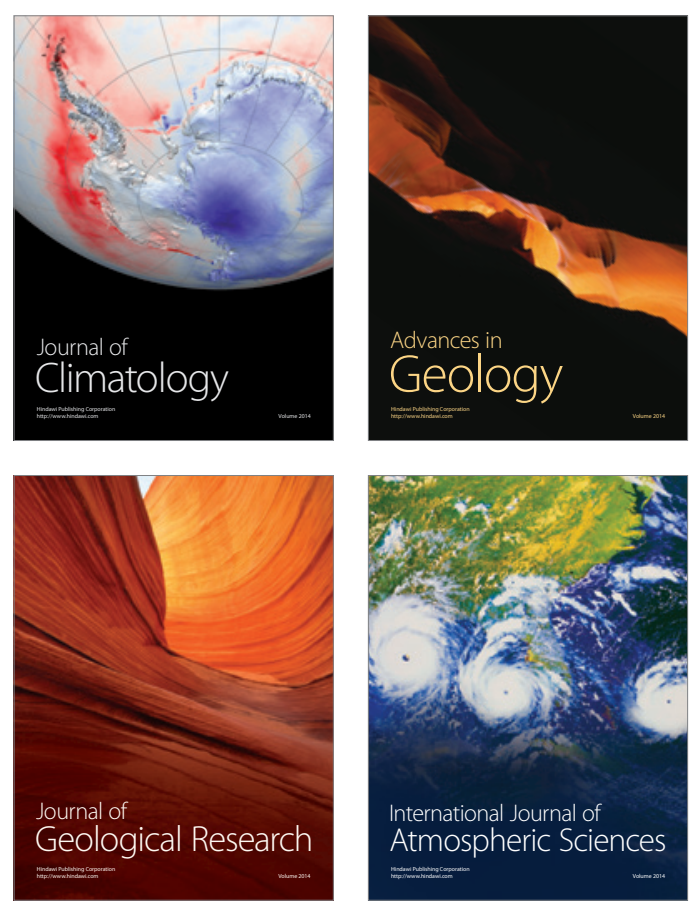
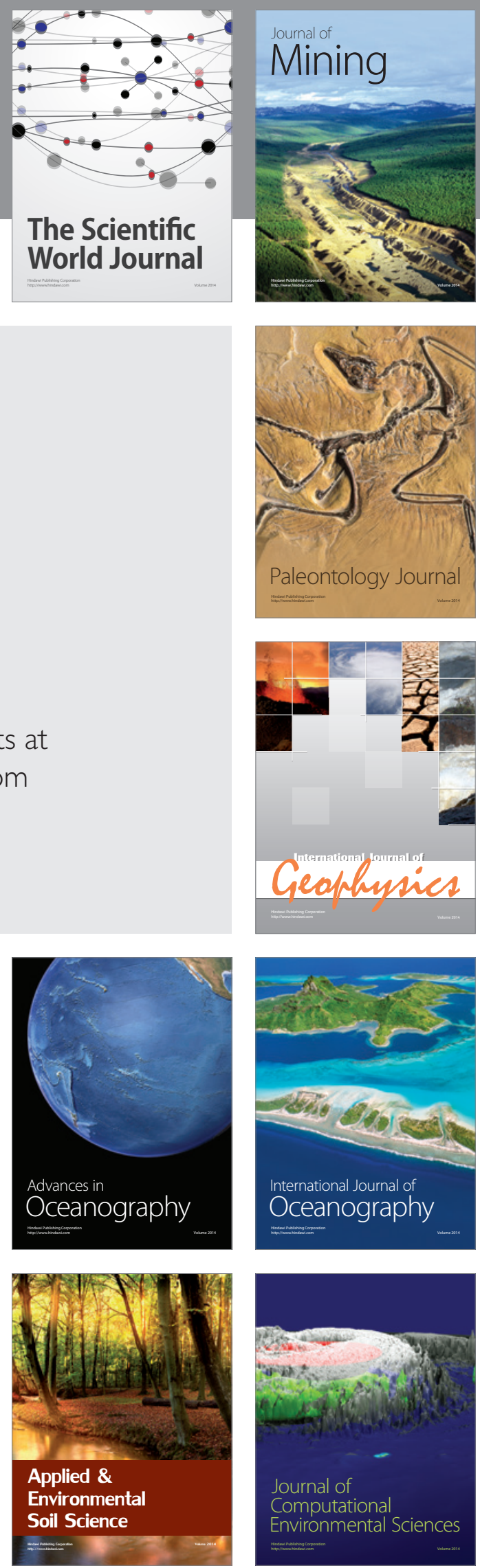